\title{
EFFECTIVE RISK MANAGEMENT SYSTEMS AT MANUFACTURING ENTERPRISES
}

\author{
Makhmudova Nodirakhon Jumaboy qizi
}

Article DOI: https://doi.org/10.36713/epra6449

\begin{abstract}
ANNOTATION
Due to changes in market conditions and a drop in the rate of development of the domestic economy, industrial enterprises have to carry out entrepreneurial activities in the face of growing uncertainty of the situation and the volatility of the economic environment. In this connection, there is ambiguity and uncertainty in obtaining the expected final result, and, therefore, there is a risk, i.e. the danger of failure, unforeseen losses. Thus, modern conditions lead to the need to develop a new strategy for managing a manufacturing enterprise operating under risk conditions, to develop a methodology for analyzing and assessing risk, as well as procedures for making and implementing managerial decisions. To successfully manage risks, you need to be able to identify, analyze and predict them. The article discusses methodological approaches to drawing up a risk management system for industrial enterprises, approaches to assessing the risks of industrial enterprises. A general scheme of a risk management system for industrial enterprises is proposed in order to analyze and assess risk, and develop ways to reduce it in production management.
\end{abstract}

KEY WORDS: risks of an industrial enterprise, efficiency of economic activity, classification signs of risks, risk assessment, methods of risk analysis, production management

\section{DISCUSSION}

A necessary condition for the effectiveness of any economic system is economic freedom, which presupposes that an economic agent (producer, consumer) has a certain set of rights that guarantee him autonomous, independent decision-making. But economic freedom is a source of uncertainty and risk, since the freedom of one economic agent is accompanied at the same time by the freedom of others.

Any activity that legal entities are engaged in is always at risk. At each stage of the formation of an enterprise, management of its activities, certain risks are formed that negatively affect and have a negative impact on the formation of the financial result.

Despite the fact that in modern economic literature there are many views on the problem of risk, which gives rise to a variety of definitions of the concept of "risk" proposed by various authors, three types of definition of this category can be formulated:

- Risk is the probability of deviation from the planned results (losses or additional profits);
- Risk is an uncertainty that can be qualitatively and / or quantified;

- Risk is an action at random in a situation of uncertainty in the hope of a positive result.

With regard to the production sphere, risk is defined as the possibility of losing part of the resources or shortfall in income in comparison with the levels and values calculated on the basis of the assumptions about the most rational use of resources and the accepted scenario of the development of the market situation.

Production risk is a risk arising from any type of activity related to the production of products, their sale, commodity-money and financial transactions, marketing, commerce, the implementation of socio-economic and scientific and technical projects.

Drawing up a system of classification signs of risk gives an understanding of its nature, allows you to establish structural characteristics, and develop measures to reduce the level of risk based on the results of its assessment.

A feature of the classification risks of industrial enterprises is its conventionality, since it is 


\section{EPRA International Journal of Research and Development (IJRD)}

Volume: 6 | Issue: 4 | April 2021

- Peer Reviewed Journal

difficult to draw a rigid division of the boundaries between types of risks, since they are all interconnected, changing and complementing each other, are of mixed nature, and can be an integral part of each other.

Table 1 presents a system of classification signs of risks of an industrial enterprise.

\begin{tabular}{|c|c|c|}
\hline $\begin{array}{c}\text { Classification } \\
\text { attribute }\end{array}$ & Type of risks & Risk characterization \\
\hline \multirow{4}{*}{$\begin{array}{l}\text { By the level of the } \\
\text { economic system }\end{array}$} & Megaeconomic & Associated with the functioning of the economy as a whole \\
\hline & Macroeconomic & Risks of the economic system of the state \\
\hline & Mesoeconomic & Formed at the level of sectors of the national economy \\
\hline & Microeconomic & Intercompany risks of an individual enterprise \\
\hline \multirow{6}{*}{ Sphere of origin } & Political & Associated with political instability, changes in legislation \\
\hline & Ecological & Associated with emergencies, environmental pollution \\
\hline & Industrial & $\begin{array}{l}\text { Associated with forced interruptions in production: loss of } \\
\text { working capital, failure of production assets }\end{array}$ \\
\hline & Commercial & $\begin{array}{l}\text { Associated with a change in the terms of the commercial } \\
\text { activities, market conditions }\end{array}$ \\
\hline & Transport & $\begin{array}{l}\text { It is associated with the safety of the cargo during } \\
\text { transportation and compliance with the delivery time }\end{array}$ \\
\hline & Financial & Associated with the likelihood of loss of financial resources \\
\hline \multirow{2}{*}{ Place of origin } & External & $\begin{array}{l}\text { Changes in economic policy, natural disasters, exchange } \\
\text { rate risk }\end{array}$ \\
\hline & Internal & $\begin{array}{l}\text { Associated with the specialization of the enterprise: } \\
\text { production, financial, insurance }\end{array}$ \\
\hline \multirow{3}{*}{$\begin{array}{l}\text { The degree of the risk } \\
\text { acceptability }\end{array}$} & Permissible & $\begin{array}{l}\text { Risk, financial losses for which do not exceed the estimated } \\
\text { amount of profit on the ongoing investment project }\end{array}$ \\
\hline & Critical & $\begin{array}{l}\text { Risk, financial losses for which do not exceed the estimated } \\
\text { amount of gross income for the investment project being } \\
\text { implemented }\end{array}$ \\
\hline & Catastrophic & $\begin{array}{l}\text { The risk for which financial losses are determined by the } \\
\text { partial or complete loss of equity capital (this type of risk } \\
\text { may be accompanied by the loss of borrowed capital) }\end{array}$ \\
\hline \multirow{2}{*}{$\begin{array}{l}\text { Possibility / } \\
\text { impossibility for } \\
\text { project participants to } \\
\text { influence risk factors }\end{array}$} & Non-systematic (internal) & $\begin{array}{l}\text { Risk associated with factors, the negative consequences of } \\
\text { which can be largely prevented through effective } \\
\text { management of project risks (quality of management, } \\
\text { structure of assets and capital, relationships with partners, } \\
\text { etc.) }\end{array}$ \\
\hline & $\begin{array}{l}\text { Systematic } \\
\text { (external) }\end{array}$ & $\begin{array}{l}\text { It is typical for all participants in investment activities and } \\
\text { all types of real investment operations. It occurs in a } \\
\text { number of cases that the company cannot influence in the } \\
\text { course of its activities (inflation risk, interest rate risk, tax } \\
\text { risk) }\end{array}$ \\
\hline \multirow{3}{*}{$\begin{array}{l}\text { By stages of project } \\
\text { implementation }\end{array}$} & Pre-investment stage risks & $\begin{array}{l}\text { Risks associated with the choice of an investment idea, the } \\
\text { preparation of business plans, recommended for the use of } \\
\text { investment goods, the validity of the assessment of the } \\
\text { main performance indicators of the project }\end{array}$ \\
\hline & Investment stage risks & $\begin{array}{l}\text { Risks of untimely implementation of construction and } \\
\text { installation work on the project; ineffective control over } \\
\text { the quality of these works }\end{array}$ \\
\hline & $\begin{array}{l}\text { Post-investment stage } \\
\text { risks }\end{array}$ & $\begin{array}{l}\text { Risks associated with untimely production reaching the } \\
\text { planned design capacity; insufficient provision of } \\
\text { production with the necessary raw materials and } \\
\text { materials; irregular supply of raw materials and supplies; } \\
\text { low qualification of operating personnel; shortcomings in } \\
\text { marketing policy, etc. }\end{array}$ \\
\hline
\end{tabular}




\section{EPRA International Journal of Research and Development (IJRD)}

Volume: 6 | Issue: 4 | April 2021

- Peer Reviewed Journal

\begin{tabular}{|l|c|l|}
\hline \multirow{2}{*}{ possibility of insurance } & Insured & $\begin{array}{l}\text { Risks that can be transferred through external insurance to } \\
\text { relevant insurance companies }\end{array}$ \\
\cline { 2 - 3 } & Uninsured & $\begin{array}{l}\text { Risks for which there is no supply of relevant insurance } \\
\text { products in the insurance market }\end{array}$ \\
\hline
\end{tabular}

The International Risk Management Standard, recognized worldwide, was developed jointly by the Risk Management Institute (IRM), the Association for Risk Management and Insurance (AIRMIC) with the participation of the National Risk Management Forum in the UK Public Sector. This standard is known as FERMA RMS. Unlike the COSO ERM Standard discussed above in terms of the terminology used, this standard follows the approach taken in the documents of the International Organization for Standardization, which is the ISO / IEC Guide 73 Risk Management - Vocabulary - Guidelines for use in standards. In particular, risk is defined by the standard as "a combination of the likelihood of an event and its consequences. Risk management in this context is considered as the central part of the strategic management of an organization, whose task is to identify and manage risks. Risk management as a unified risk management system should include a program for monitoring the implementation of assigned tasks, an assessment of the effectiveness of measures taken, as well as a reward system at all levels of the organization. In accordance with the FERMA Standard, four groups of organization risks are distinguished: strategic, operational and financial, as well as hazard risks. In addition, the methods presented in the ISO standards are the basis for the risk assessment in the FERMA RMS standard. The creators of the standards agree with ISO / IEC that risk assessment is an analysis of risk, as well as its qualitative and quantitative assessment.

Today, there are a large number of risk minimization methods presented by various scientists.

The main ways to minimize risks include: risk distribution among different agents, risk insurance, self-insurance of risks, organization of production diversification, limitation, implementation of alternative planning, creation of a flexible production structure, creation of reserve funds, information monitoring, training and training of personnel, the use of flexible technologies, risk aversion.

Taking into account the sectoral characteristics of industrial enterprises in production management, it is necessary to highlight the methods of risk reduction aimed at resource provision of production and effective supply activities (Table 2 ).

Table 2

Ways to reduce risk in the production management of industrial enterprises

\begin{tabular}{|c|l|}
\hline \multicolumn{1}{|c|}{ Types of risk } & \multicolumn{1}{c|}{ Ways to reduce your risk } \\
\hline \multicolumn{2}{|c|}{ In the field of production } \\
\hline Technical risk & \multicolumn{1}{|c|}{ Carrying out preventive measures, formation of reserve funds, insurance } \\
\hline Technological risk & Quality control, situation monitoring \\
\hline Production organization risk & $\begin{array}{l}\text { Development of promising areas of development, building a rational } \\
\text { production structure, pursuing an effective innovation and investment } \\
\text { policy }\end{array}$ \\
\hline Labor resource risk & $\begin{array}{l}\text { Professional development, personnel training, certification, accident } \\
\text { insurance }\end{array}$ \\
\hline Executive risk & $\begin{array}{l}\text { Methods of motivating employees, contributing to the achievement of the } \\
\text { goals of the enterprise (association) }\end{array}$ \\
\hline Natural disaster risk & Insurance, self-insurance - formation of reserve funds \\
\hline & $\begin{array}{l}\text { Integration processes (conclusion of long-term contracts, agreements), } \\
\text { diversification of production }\end{array}$ \\
\hline Market risk & Self-insurance, introduction of penalties, forfeits \\
\hline Transport risk & Introduction of resource-saving, energy-saving technologies \\
\hline Warehouse risk & Implementation of scientific inventory management methods \\
\hline Risk of purchasing raw \\
materials
\end{tabular}




\section{EPRA International Journal of Research and Development (IJRD) \\ Volume: 6 | Issue: 4 | April 2021 \\ - Peer Reviewed Journal}

In many ways, the reasons for the low competitiveness of industrial enterprises are the lack of a specialized contour (and/or special functions) for risk management in their management system. Risk management of industrial enterprises must be holistic and orderly in a certain way. For the integrity and orderliness of risk management, this system can be represented as the following diagram:

\section{Risk object analysis}

Identifying and assessing the causes of risk
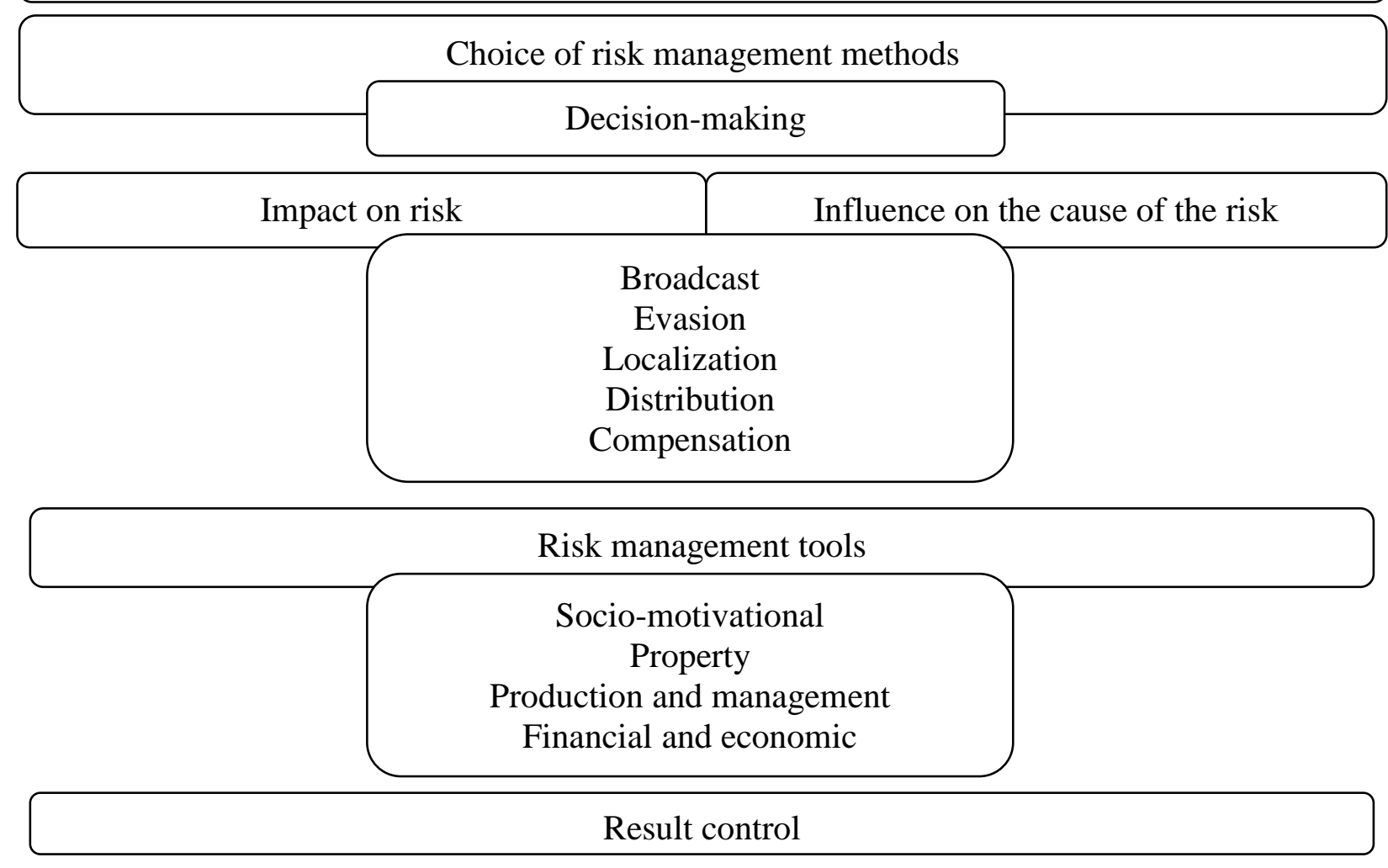

Fig. 3. General scheme of the risk management system of industrial enterprises

Let us give a description of each element of the risk management system of an industrial enterprise. In accordance with the presented scheme, the first element is a risk analysis subsystem, the purpose of which is to obtain information about the structure, properties of an industrial enterprise at the present time and changes in its state in the future;

The second element is identifying, characterizing and assessing the existing causes of risks of an industrial enterprise, determining the likelihood of the size and possible damage;

The third element is responsible for choosing a method for developing a management decision aimed either at eliminating the cause or at minimizing the consequences;

The fourth element implements the process of influencing the risk, which consists in the application of specific methods of influencing the risk;
In the fifth element, the choice of risk management tools is carried out, and in the sixth stage, the result of the implementation of measures for risk management of machine-building enterprises is monitored. The system should be filled with risk management tools.

Modern economic conditions in which industrial enterprises operate, lead to the need to improve the risk accounting system, the basis of which is the classification of risk.

Industrial risks of enterprises should be considered the risks arising in the process of economic activity of enterprises of the main industries, which may have the nature of large, special or natural disaster risks.

The considered methodological recommendations for the analysis and assessment of risk will make it possible to build an effective risk prevention mechanism, focused on solving the 


\section{EPRA International Journal of Research and Development (IJRD) \\ Volume: 6 | Issue: 4 | April 2021

problems of stabilization and development of industrial enterprises, can be used as a toolkit in the procedure for making and implementing decisions in production management.

\section{REFERENCES}

1. Lankina S.A., Flegontov V.I. Klassifikatsiya $i$ problemi otsenki riskov promishlennogo predpriyatiya //Internet-jurnal «NAUKOVeDeNIe» Tom 7, №2 (2015) http://naukovedenie.ru/PDF/90EVN315.pdf. Zagl. s ekrana. Yaz. rus., angl. DOI: 10.15862/90EVN315

2. Vanyurixin F.G. Upravlenie riskom kak dinamicheskaya zadacha. /F.G.Vanyurixin // Nauchniy vestnik MGU im. M.V. Lomonosova. 2010.

3. Ivanov A.A., Oleynikov S.Ya.,Bocharov S.A.Riskmenedjment. Uchebno-metodicheskiy kompleks M.: Izd. sentr yeAOI, 2008

4. Simonenko N.N., Simonenko V.N. Types and functions of business risks //International journal of applied and fundamental research. - 2013. - № 11-1.

5. Khankeldieva G.Sh. Theoretical and Economic Prerequisites for the Development of Regional Industrial Clusters in the Economy of the Republic of Uzbekistan // EPRA International Journal of Research and Development (IJRD). 2020. pp. 234240. https://doi.org/10.36713/epra 4855.

6. Maxmudova, N. J. (2020). Theoretical foundations of risk management in large corporate structures. ISJ Theoretical \& Applied Science, 06 (86), 83-88. Soi: $\quad$ http://s-o-i.org/1.1/TAS-06-86-15 Doi: https://dx.doi.org/10.15863/TAS.2020.06.86.15

7. Kambarov J.X., Maxmudova N.J.K. Zadachi upravleniya riskami na predpriyatii // Jurnal nauchnblx publikatsiy aspirantov $i$ doktorantov, $\begin{array}{lllll}2016 . & \text { № } & 5 . & \text { S. } & 88-89\end{array}$ https://www.elibrary.ru/item.asp? $\mathrm{S} d=26240779$

8. Ashurov Maxammadjon Sotvoldievich, Shakirova Yulduz Saydalievna Voprosbl ustoychivogo razvitiya promblshlennblx predpriyatiy Uzbekistana v usloviyax riska // Problembl Nauki. 2019. №4 (137). URL: https://cyberleninka.ru/article/n/voprosyustoychivogo-razvitiya-promyshlennyhpredpriyatiy-uzbekistana-v-usloviyah-riska 